\title{
Analysis of Associations Between the Prion Protein Genotypes and Production Traits in East Friesian Milk Sheep
}

\author{
F. De Vries, ${ }^{1}$ H. Hamann, ${ }^{1}$ C. Drögemüller, ${ }^{1}$ M. Ganter, ${ }^{2}$ and O. Distl ${ }^{1}$ \\ ${ }^{1}$ Institute for Animal Breeding and Genetics and \\ ${ }^{2}$ Clinic for Pigs and Small Ruminants, Forensic Medicine and Ambulatory Service, \\ University of Veterinary Medicine Hannover, Foundation, 30559 Hannover, Germany
}

\section{ABSTRACT}

The objective of this study was to analyze associations between ovine prion protein genotypes and production traits in East Friesian milk sheep. Production traits included the type traits scores for muscle mass, wool quality, and type; the reproduction traits age at first lambing, first lambing interval, second lambing interval, and total number of lambs born; the milk performance traits; milk, fat, and protein yields; fat and protein contents; and somatic cell scores. Prion protein genotypes were available for 658 East Friesian milk sheep. Linear animal models were used for the analysis of the prion protein genotype effects. The scores of the genotyped sheep for muscle mass, type, wool quality, and fat yield were significantly superior to those of the nongenotyped animals. An explanation for this might be that breeders seek to minimize genotyping costs by preselecting animals that do not meet the top breeding requirements. No significant associations were found between the prion protein genotypes and milk performance, type, or reproduction traits.

(Key words: prion protein, scrapie, performance trait, milk sheep)

Abbreviation key: PrP = prion protein.

\section{INTRODUCTION}

Research has shown that certain prion protein $(\mathbf{P r P})$ genotypes in sheep confer resistance to scrapie (Goldmann et al., 1991; Hunter et al., 1994). Polymorphisms in the ovine PrP gene at codons 136, 154, and 171 determine the susceptibility of individual animals (Belt et al., 1995; Hunter et al. 1996). Different studies have shown that sheep homozygous for the ARR allele of the PrP gene are resistant to natural and experimental oral scrapie infections, whereas animals carrying the VRQ

Received December 17, 2003.

Accepted August 29, 2004.

Corresponding author: F. De Vries; e-mail: frerich.de.vries@ tiho-hannover.de. allele are at greatest risk (Heggebø et al., 2002, 2003). In breeds such as East Friesian milk sheep in which the VRQ allele is not present (Drögemüller et al., 2004), ARQ-homozygous animals are highly susceptible to scrapie infections (Hunter et al., 1997). Scrapie in sheep can be controlled by breeding for the resistant ARR/ ARR genotype. European Union regulations require each member state to introduce a breeding scheme to select for resistance to transmissible spongiform encephalopathies in each of its sheep breeds (Commission Decision, 2003/100/EC). The breeding programs are aimed to increase the frequency of the ARR allele and reduce the prevalence of those alleles that have been shown to contribute to susceptibility to transmissible spongiform encephalopathies. Because of the low ARR allele frequencies found in East Friesian milk sheep, conditions for breeding toward scrapie resistance are unfavorable in this breed. Two main issues arise in such a situation. The first is whether the intensive use of a low number of breeding rams carrying the desired ARR allele will cause genetic drift, increased rates of inbreeding, and reduced additive genetic variance in future generations. The second is whether there are negative associations of the ARR allele or ARR/ARR genotype with production traits. An effective monitoring of breed characteristics in East Friesian milk sheep must be established to answer these questions. East Friesian milk sheep are well known for their prolificacy and milk production capacity. Parry (1983) suggested that the meat quality of scrapie-susceptible animals was far superior to that of scrapie-resistant animals. However, a study performed in the United Kingdom found no significant influence of the PrP alleles/genotypes on a lean Growth Index score including scanning weight and ultrasonic measurements of fat depth and muscle depth in a Scottish Suffolk herd (Prokopová et al., 2002), nor were any negatively significant associations quantifiable between meat performance traits and ARR allele or ARR/ARR genotype in German meat sheep breeds (De Vries et al., 2004a). The first study for meat sheep breeds that showed significant associations between the different PrP alleles or genotypes in sheep was done by Brandsma et al. (2004). The results from 
Table 1. Total number of animals and number of genotyped animals and their PrP allele frequencies over the birth years with records for the traits muscle mass, type, and wool quality.

\begin{tabular}{|c|c|c|c|c|c|c|}
\hline \multirow{2}{*}{$\begin{array}{l}\text { Year } \\
\text { of birth }\end{array}$} & \multirow{2}{*}{$\begin{array}{l}\text { Total } \\
\text { animals } \\
\text { (no.) }\end{array}$} & \multirow{2}{*}{$\begin{array}{l}\text { Genotyped } \\
\text { animals } \\
\text { (no.) }\end{array}$} & \multirow{2}{*}{$\begin{array}{l}\text { Fraction of } \\
\text { genotyped } \\
\text { animals }\end{array}$} & \multicolumn{3}{|c|}{$\mathrm{PrP}$ allele frequencies } \\
\hline & & & & AHQ & $\mathrm{ARQ}$ & $\mathrm{ARR}$ \\
\hline 1992 & 52 & 2 & 0.04 & 0.25 & 0.50 & 0.25 \\
\hline 1993 & 54 & 1 & 0.02 & - & 1.00 & - \\
\hline 1994 & 72 & 3 & 0.04 & 0.17 & 0.83 & - \\
\hline 1995 & 170 & 12 & 0.07 & 0.34 & 0.58 & 0.08 \\
\hline 1996 & 337 & 21 & 0.06 & 0.26 & 0.71 & 0.03 \\
\hline 1992-1996 & 685 & 39 & 0.06 & 0.27 & 0.68 & 0.05 \\
\hline 1997 & 517 & 49 & 0.09 & 0.41 & 0.53 & 0.06 \\
\hline 1998 & 546 & 62 & 0.11 & 0.36 & 0.56 & 0.08 \\
\hline 1999 & 494 & 63 & 0.13 & 0.29 & 0.66 & 0.05 \\
\hline 2000 & 549 & 104 & 0.19 & 0.40 & 0.54 & 0.06 \\
\hline 2001 & 545 & 116 & 0.21 & 0.30 & 0.58 & 0.12 \\
\hline 2002 & 527 & 164 & 0.31 & 0.36 & 0.47 & 0.17 \\
\hline 2003 & 101 & 61 & 0.60 & 0.30 & 0.28 & 0.42 \\
\hline Total & 3964 & 658 & 0.17 & 0.34 & 0.53 & 0.13 \\
\hline
\end{tabular}

that study indicate that the current implementation of the Dutch accelerated eradication program by selecting ARR/ARR rams has a small positive effect for litter size and a small negative effect for 135-d weight in the analyzed Texel population. For milk sheep breeds, only one study was done. The analysis of the relationships between the different PrP alleles of rams and the milk performance traits of their daughters in 2 French milk sheep breeds revealed no significant associations (Barillet et al., 2002). No study for the PrP genotypes of dairy ewes and their milk production traits has been done until now.

The aim of this work was to assess whether there is an association between the PrP genotype and production traits used in selecting rams and ewes of East Friesian milk sheep.

\section{MATERIALS AND METHODS}

The PrP alleles were determined in 658 animals born in the years 1992 to 2003 by direct sequencing of PCR products as previously described (Drögemüller et al., 2001). The total number of 658 examined animals from 65 flocks includes almost all available breeding sheep of Northern Germany, including the region of origin of this breed. For this analysis, the 15 ARR homozygous animals were excluded because of the low number (Table 1). The sample included animals sampled by the breeders and about 250 animals randomly sampled by us. For these genotyped animals and all contemporary companions, the herd-book data from the years 1992 to 2003 for 3949 East Friesian milk sheep from 140 flocks were provided by 3 German regional breeding organizations. All flocks used natural service sires; there was no artificial insemination. There is an exchange of rams and ewes between the 3 breeding regions and flocks.
Three datasets were edited for the analysis (Table 2 ). The original data set included information for rams and ewes licensed for the herd-book in the years 1992 to 2002 with respect to scores for muscle mass, wool quality, and type. Reproduction traits and monthly recorded milk performance traits were provided in separate data sets.

Milk sheep in Germany are evaluated for muscle mass, wool quality, and type at the day of licensing. These traits were scored on a scale from 1 to 9 , where 9 = best score and $1=$ poorest score. For the analysis of these traits, we developed a linear animal model that included the day of licensing as a fixed effect. Test days with $<6$ observations were extended to classes by including the subsequent test days. The model used for analyzing these 3 traits (model 1) included the fixed effects of PrP genotype, flock-year-season, test-day-class, sex, birth rearing type, the covariate of age at licensing, and the random additive genetic effect of the animal. The birth year was divided into a main season (January to March) and a secondary season (April to December). Classes of flock-year-seasons with only one record were excluded. We distinguished among 3 birth types: animals born as singles, twins, or triplets and quadruplets. The model selected was

$$
\begin{aligned}
\mathrm{y}_{\mathrm{ijk} k \mathrm{lmnr}}=\mu & +\operatorname{PrP}_{\mathrm{i}}+\mathrm{FYS}_{\mathrm{j}}+\mathrm{TD}_{\mathrm{k}}+\mathrm{G}_{\mathrm{l}}+\mathrm{GT}_{\mathrm{m}} \\
& +\mathrm{b} \mathrm{A}_{\mathrm{n}}+\mathrm{a}_{\mathrm{r}}+\mathrm{e}_{\mathrm{ijklmnr}}
\end{aligned}
$$

where $\mathrm{y}_{\mathrm{ijklmnr}}$ is the muscle mass, wool quality, or type record of animal $r$ with $\operatorname{PrP}$ genotype $i$, in herd-yearseason $\mathrm{j}$, on test-day $\mathrm{k}$, with sex $\mathrm{l}$, with birth rearing type $\mathrm{m}$, at the age at licensing $\mathrm{n}$, with additive genetic effect $\mathrm{r} ; \mu$ is a model constant; $\operatorname{PrP} \mathrm{P}_{\mathrm{i}}$ is the effect of $\operatorname{PrP}$ genotypes ( $\mathrm{i}=1$ to 3 ); $\mathrm{FYS}_{\mathrm{j}}$ is the fixed effect of flockyear-season ( $\mathrm{j}=1$ to 416$) ; \mathrm{TD}_{\mathrm{k}}$ is the fixed effect of test 
day $(k=1$ to 98$) ; G_{l}$ is the fixed effect of sex $(l=1$ to $2) ; \mathrm{GT}_{\mathrm{m}}$ is the fixed effect of birth rearing type $(\mathrm{m}=1$ to 3 ); $b$ is the linear regression coefficient; $A_{n}$ is the age at licensing; $a_{r}$ is the random additive genetic effect of the animal ( $r=1$ to 7111$)$; and $e_{i j k l m n r}$ is the residual effect. The PrP-genotype effects were analyzed in $3 \mathrm{PrP}$ genotype classes. The first class included only the sheep heterozygous for the ARR allele; the second class, the genotyped sheep without the ARR allele; and the third class, all sheep of unknown genotype.

The reproduction traits age at first lambing, lambing interval, and total number of lambs born are based on lambing information of ewes from the breeding flocks. The database included 7620 lambing records, with 2410 records of age at first lambing, 1740 records of the firstlambing interval between the first and second litters, 1184 records of second-lambing interval between the second and third lambings, and 4959 records of total number of lambs born. We used a linear animal model to analyze the reproduction traits. This model included the year-season, the flock, and the PrP genotype as fixed effects (model 2) and the random additive genetic effect of the animal.

$$
\begin{aligned}
\mathrm{y}_{\mathrm{ijkr}}=\mu & +\operatorname{PrP}_{\mathrm{i}}+\mathrm{YS}_{\mathrm{j}}+\mathrm{F}_{\mathrm{k}}+\mathrm{a}_{\mathrm{r}}+\mathrm{e}_{\mathrm{ijkr}} \\
\mathrm{y}_{\mathrm{ijkl} l q r s}= & \mu+\operatorname{PrP}_{\mathrm{i}}+\mathrm{YS}_{\mathrm{j}}+\mathrm{F}_{\mathrm{k}}+\mathrm{LN}_{\mathrm{l}} \\
& +\mathrm{p}_{\mathrm{q}}+\mathrm{a}_{\mathrm{r}}+\mathrm{e}_{\mathrm{ijk} \mathrm{klqrs}}
\end{aligned}
$$

where $\mathrm{y}_{\mathrm{ijkr}}$ is the age at first lambing, first-lambing interval, or second-lambing interval record of the ewe $\mathrm{r}$ with PrP genotype $\mathrm{i}$, in year-season $\mathrm{j}$, in flock $\mathrm{k}$, with additive genetic effect $\mathrm{r} ; \mu$ is a model constant; $\mathrm{YS}_{\mathrm{j}}$ is the fixed effect of year-season ( $\mathrm{j}=1$ to 22$) ; \mathrm{F}_{\mathrm{k}}$ is the fixed effect of flock ( $\mathrm{k}=1$ to 140); random additive genetic effect of the ewe ( $r=1$ to 4790$)$; and other effects are as defined previously.

The model (model 3) selected for total number of born lambs was extended by the fixed effect of class of litter number and by the random permanent environmental effect of the animal: $y_{\mathrm{ijkl}}$ irs is the total number born lambs recorded of the ewe $\mathrm{n}$ with $\mathrm{PrP}$ genotype $\mathrm{i}$, in year-season $\mathrm{j}$, in flock $\mathrm{k}$, in litter number $\mathrm{l}$, with random permanent environmental effects $\mathrm{q}$, with additive genetic effect $\mathrm{r} ; \mu$ is a model constant; $\mathrm{LN}_{\mathrm{l}}$ is the fixed effect of litter number ( $1=1$ to 6$)$; $\mathrm{p}_{\mathrm{q}}$ is the random permanent environmental effect of the animal $(q=1$ to 2528); $\mathrm{a}_{\mathrm{r}}$ is the random additive genetic effect of the animal ( $\mathrm{r}=1$ to 4790$)$; and other effects were as defined previously.

Similar to birth year in model 1, lambing year was divided into a main season (January to March) and a secondary season (April to December). Because of the low number of observations, litter numbers $>5$ were considered together in a single litter number class.

Records of 915 dairy ewes observed between 1992 and 2002 were used to analyze the association between the PrP genotype and milk performance traits. These records included 6749 test-day records for milk, fat, and protein yields; fat and protein contents; and SCC of 1202 lactations. Test-day records were taken at 4-wk intervals according to the official ICAR protocols for method A4. Test-day SCC were transformed to the SCS by logarithmic transformation: $\mathrm{SCS}=\log _{2}\left(\left(\mathrm{SCC} / 10^{5}\right)\right.$ $+3)$. For analysis of these traits, we used the linear test-day model with fixed regression developed by Hamann et al. (2004) and extended by the PrP genotype effect:

$$
\begin{gathered}
\mathrm{y}_{\mathrm{ijklmnopqrs}}=\mu+\operatorname{PrP}_{\mathrm{i}}+\mathrm{R}_{\mathrm{j}}+\mathrm{S}_{\mathrm{k}}+\mathrm{Y}_{\mathrm{l}}+\mathrm{L}_{\mathrm{m}}+\mathrm{TI}_{\mathrm{n}} \\
+\mathrm{f}_{\mathrm{o}}\left(\mathrm{R}_{\mathrm{j}}\right)+\mathrm{b}_{1} \mathrm{DIM}_{\mathrm{p}}+\mathrm{b}_{2}\left(\mathrm{DIM}_{\mathrm{p}}\right)^{2}+\mathrm{b}_{3} \log \mathrm{DIM}_{\mathrm{p}} \\
+\mathrm{b}_{4}\left(\log \mathrm{DIM}_{\mathrm{p}}\right)^{2}+\mathrm{p}_{\mathrm{q}}+\mathrm{a}_{\mathrm{r}}+\mathrm{e}_{\mathrm{ijklmnopqr}}
\end{gathered}
$$

where $\mathrm{y}_{\mathrm{ijklmnopgrs}}$ is the daily milk record for milk yield, fat yield, protein yield, fat content, protein content, or SCS record of animal $r$ with $\operatorname{PrP}$ genotype $i$, in region $\mathrm{j}$, in lambing season $\mathrm{k}$, in lambing year $\mathrm{l}$, with lactation number $\mathrm{m}$, on test day interval $\mathrm{n}$, in flock $\mathrm{o}$, with DIM $p$, with random permanent environmental effect $q$, with additive genetic effect $r ; \mu$ is a model constant; $R_{j}$ is the fixed effect of the region ( $j=1$ to 3 ); $S_{k}$ is the fixed effect of the lambing season ( $\mathrm{k}=1$ to 5$) ; \mathrm{Y}_{1}$ is the fixed effect of the lambing year ( $\mathrm{l}=1$ to 11$) ; \mathrm{L}_{\mathrm{m}}$ is the fixed effect of lactation number ( $\mathrm{m}=1$ to 6 ); $\mathrm{TI}_{\mathrm{n}}$ is the fixed effect of test day interval ( $n=1$ to 82$) ; f_{0}\left(R_{j}\right)$ is the random effect of the flock within region ( $0=1$ to 246 ); $\mathrm{DIM}_{\mathrm{p}}$ is DIM as covariate; $b_{1}-b_{4}$ are regression coefficients; $p_{q}$ is the random permanent environmental effect of the animal ( $q=1$ to 915$) ; a_{r}$ is the random additive genetic effect of the animal ( $r=1$ to 2298); and other effects are as defined previously.

The random additive genetic effect of the animal was included in all models to explain the residual quantitative genetic variation in addition to the PrP genotype effect and to take into account a possible genetic trend in the traits investigated. Genetic parameters were estimated by univariate analysis of all described performance traits using VCE4 (Groenevald, 1998). Linear contrasts between $2 \mathrm{PrP}$ genotype classes and the nongenotyped animals were calculated for each performance trait using the program PEST, version 3.1 (Groeneveld, 1993). Additionally, we estimated the ARR allele substitution effects for all traits; however, the models used here included a linear regression on the number of ARR alleles present in each animal instead of the PrP genotype effect. For the analysis of the ARR 
Table 2. Number of animals used in the different data sets and distribution of East Friesian milk sheep by the PrP genotype.

\begin{tabular}{lllll}
\hline & & $\begin{array}{l}\text { Data set } 1 \\
\text { for muscle } \\
\text { mass, type, } \\
\text { and wool } \\
\text { quality }\end{array}$ & $\begin{array}{l}\text { Data set 2 for } \\
\text { reproduction } \\
\text { traits }\end{array}$ & $\begin{array}{c}\text { Data set } 3 \\
\text { for milk } \\
\text { performance } \\
\text { traits }\end{array}$ \\
\hline & PrP genotype & 15 & 6 & 2 \\
1 & ARR/ARR & 144 & 60 & 33 \\
3 & ARR/xxx $^{1}$ & 499 & 371 & 225 \\
3 & xxx $^{1} / \mathrm{xxx}^{1}$ & 3306 & 2097 & 657 \\
& Not genotyped $^{\text {Total }}$ & 3949 & 2528 & 915 \\
\hline
\end{tabular}

${ }^{1} \mathrm{xxx}=\mathrm{AHQ}, \mathrm{ARQ}$ alleles.

${ }^{2}$ Total = without ARR homozygous animals.

allele substitution effects, we excluded the nongenotyped and the ARR homozygous animals.

\section{RESULTS AND DISCUSSION}

The favorable ARR allele occurred at a low frequency of $13 \%$ in the total data set and of $7 \%$ in the sample randomly collected by us in East Friesian milk sheep. The most prevalent PrP alleles were the ARQ allele and the AHQ allele. The VRQ or ARH allele has not yet been found in East Friesian milk sheep. The ARR heterozygous animals were almost all related to each other. This already reveals the problems of breeding toward scrapie resistance in a breed with a low ARR allele frequency. Although exceptions are mentioned in the European Union legislations, the breeders are trying to reach the status of 'scrapie resistant' as far as possible because of marketing aspects, despite the fact that negative effects may exist or high inbreeding rates and a bottleneck effect are to be expected. There are significant concerns about losing the breed's characteristics. Further studies to develop the optimal breeding scheme toward scrapie resistance are needed to keep theses negative effects as small as possible. Possible solutions include using only ARR heterozygous rams until the ARR allele frequency reaches a certain value.

Table 3 shows the means and their standard deviations, additive genetic variances, heritabilities, and their standard errors of the traits analyzed. The estimated heritabilities of the traits muscle mass, type, and wool quality were in the ranges reported by Stier et al. (1988) and by Savas et al. (2001) for German meat sheep breeds, and in the range reported by De Vries et al. (2004b,c) for German milk, meat, and land sheep breeds.

Age at first lambing and at first- and second-lambing intervals showed high standard deviations, which is in agreement with the results of Savas et al. (2000) and De Vries et al. (2004b,c). High means for total number born lambs reflect the high reproduction rate of this breed. Moderately large age at first lambing heritability estimates have also been found for meat sheep breeds (Savas et al., 2000) and for land sheep breeds (De Vries et al., 2004c). The low heritability for total number born lambs was similar to the findings of other studies (Ligda et al., 2000; Matika et al., 2003; Hamann et al., 2004). Heritability estimates for the milk performance traits were low to moderate and in agreement with Hamann et al. (2004). Except for the SCS for milk performance traits, higher heritability estimates have been reported for French Lacaune dairy sheep by Barrillet and Boichard (1987) and by Rupp et al. (2002) and for Spanish Churra milk sheep by El-Saied et al. (1998). Hamann et al. (2004) supposed that these low to moderate heritabilities of the East Friesian sheep breed in Germany could be an effect of test day records or small paternal half-sib groups, or because the flocks were small and artificial insemination was not used as a standard routine for reproduction. In general, the estimated heritabilities were in the expected ranges, except for milk performance traits.

We observed significant differences between the sheep selected for PrP genotyping and the nongenotyped sheep in muscle mass, wool quality, type, and fat yield (Table 4). In general, the nongenotyped animals showed significantly lower performances than genotyped ones over all birth years and within groups of birth years. An explanation for this observation might be that breeders seek to minimize genotyping costs by preselecting animals that do not meet the top breeding requirements. Moreover, Table 3 shows the contrasts estimated between the 2 genotype classes of the genotyped sheep for every trait examined. There were no significant differences between the different genotypes, which indicates that animals carrying the ARR allele had no significantly higher or lower performances than non-ARR carriers. The same results were obtained for the ARR allele substitution effects, as there were no significant linear regressions on the ARR allele for any performance trait regarded here (Table 5). Thus, we 
Table 3. Means and SD, additive genetic variances $\left(\sigma_{\mathrm{a}}^{2}\right)$, and heritabilities $\left(\mathrm{h}^{2}\right)$ and $\mathrm{SE}$ for performance traits in East Friesian milk sheep.

\begin{tabular}{lcccc}
\hline Trait & Mean & (SD) & \multicolumn{1}{c}{$\sigma_{\mathrm{a}}^{2}$} & $\mathrm{~h}^{2}(\mathrm{SE})$ \\
\hline Muscle mass (1 to 9) & 7.1 & $(0.6)$ & 0.056 & $0.185(0.024)$ \\
Type (1 to 9) (1 to 9) & 6.8 & $(0.7)$ & 0.035 & $0.095(0.021)$ \\
Wool quality & $(0.6)$ & 0.035 & $0.131(0.024)$ \\
Age at first lambing, d & 3.0 & $(32.1)$ & 299.1 & $0.366(0.030)$ \\
First-lambing interval, d & 386.2 & $(65.9)$ & 974.1 & $0.287(0.025)$ \\
Second-lambing interval, d & 359.0 & $(55.5)$ & 231.1 & $0.077(0.042)$ \\
Total lambs born, no. & 2.1 & $(0.7)$ & 0.037 & $0.083(0.010)$ \\
Milk yield, kg & 2.52 & $(1.28)$ & 0.093 & $0.101(0.014)$ \\
Fat content, \% & 5.66 & $(1.5)$ & 0.168 & $0.087(0.014)$ \\
Fat yield, g & 136.9 & $(75.7)$ & 525.8 & $0.120(0.015)$ \\
Protein content, \% & 4.98 & $(1.0)$ & 0.071 & $0.117(0.016)$ \\
Protein yield, g & 120.7 & $(59.4)$ & 231.6 & $0.094(0.014)$ \\
SCS & 4.43 & $(2.3)$ & 0.616 & $0.115(0.025)$ \\
\hline
\end{tabular}

were able to show that there was no association between the ARR allele and milk performance, type, or reproduction traits in milk sheep breeds. Our investigation differs from that of Barillet et al. (2002), who used only PrP genotyping results of rams and no genotyping results of ewes. They found that the milk performance of daughters of rams carrying the favorable ARR allele was similar to that of daughters of rams carrying other PrP alleles. Therefore, the results of the French study do agree with ours. However, one must view with caution the missing association between the ARR allele and milk performance in French dairy sheep, because no genotypes were observed for the ewes with milk records. On the other hand, the population size of the East Friesian milk sheep and the genetic relationship between breeding flocks in our study is much lower than that for other breeds, such as the French Lacaune or Spanish breeds, nor have significant associations been shown between the different $\mathrm{PrP}$ alleles or between genotypes and performance traits in other studies analyzing data from meat sheep breeds (Prokopová et al., 2002; De Vries et al., 2004a). As in many other studies, we were not able to find any evidence of an unfavorable association between the ARR allele and milk perfor-

Table 4. Test for significant differences $(\Delta)$ between the performance traits and the PrP genotype classes in East Friesian milk sheep.

\begin{tabular}{|c|c|c|c|c|c|c|}
\hline \multirow[b]{2}{*}{ Trait } & \multicolumn{2}{|c|}{$\mathrm{ARR} / \mathrm{xxx}^{1}$ to $\mathrm{xxx}^{1} / \mathrm{xxx}^{1}$} & \multicolumn{2}{|c|}{$\mathrm{xxx}^{1} / \mathrm{xxx}^{1}$ to $\mathrm{NG}^{2}$} & \multicolumn{2}{|c|}{$\mathrm{ARR} / \mathrm{xxx}^{1}$ to $\mathrm{NG}^{2}$} \\
\hline & $\Delta(\mathrm{SE})$ & $\mathrm{P}^{3}$ & $\Delta(\mathrm{SE})$ & $\mathrm{P}^{3}$ & $\Delta(\mathrm{SE})$ & $\mathrm{P}^{3}$ \\
\hline Muscle mass ( 1 to 9 ) & $-0.07(0.06)$ & NS & $0.20(0.03)$ & $* * *$ & $0.13(0.06)$ & * \\
\hline Type (1 to 9 ) & $-0.02(0.07)$ & NS & $0.23(0.04)$ & $* * *$ & $0.21(0.07)$ & \\
\hline Wool quality (1 to 9 ) & $-0.05(0.06)$ & NS & $0.07(0.03)$ & * & $0.02(0.06)$ & NS \\
\hline Age at first lambing, $d$ & $-1.96(4.45)$ & NS & $3.06(4.49)$ & NS & $1.09(2.23)$ & NS \\
\hline First-lambing interval, d & $2.35(10.8)$ & NS & $1.16(10.8)$ & NS & $-1.19(4.99)$ & NS \\
\hline Second-lambing interval, $d$ & $-2.77(12.0)$ & NS & $-6.39(12.1)$ & NS & $-3.62(5.55)$ & NS \\
\hline Total born lambs, no. & $-0.05(0.08)$ & NS & $0.01(0.08)$ & NS & $0.06(0.04)$ & NS \\
\hline Milk yield, kg & $0.03(0.09)$ & $\mathrm{NS}$ & $0.07(0.05)$ & NS & $0.10(0.09)$ & NS \\
\hline Fat content, $\%$ & $-0.06(0.12)$ & NS & $0.06(0.06)$ & NS & $-0.00(0.12)$ & NS \\
\hline Fat yield, g & $1.95(5.92)$ & NS & $7.30(2.94)$ & $* *$ & $9.25(5.99)$ & $\mathrm{N}$ \\
\hline Protein content, $\%$ & $-0.06(0.06)$ & NS & $-0.04(0.03)$ & NS & $-0.09(0.07)$ & \\
\hline Protein yield, $\mathrm{g}$ & $1.61(4.76)$ & NS & $2.44(2.37)$ & NS & $4.05(4.81)$ & NS \\
\hline SCS & $0.29(0.27)$ & NS & $-0.10(0.14)$ & NS & $0.18(0.27)$ & NS \\
\hline
\end{tabular}

${ }^{1} \mathrm{xxx}=\mathrm{AHQ}, \mathrm{ARQ}$ alleles.

${ }^{2} \mathrm{NG}=$ Not genotyped.

${ }^{3}$ Bonferroni correction lowers the $5 \%$ error probabilities to 0.017 .

$* P \leq 0.05$.

$* * P \leq 0.01$

$* * * P \leq 0.001$. 
Table 5. ARR allele substitution effects (b) and their standard errors on performance traits in East Friesian milk sheep.

\begin{tabular}{lcc}
\hline & \multicolumn{2}{c}{ ARR to $\mathrm{xxx}^{1}$} \\
\cline { 2 - 3 } Trait & $\mathrm{b}$ (SE) & $P$ \\
\hline Muscle mass (1 to 9) & $-0.03(0.08)$ & $\mathrm{NS}$ \\
Type (1 to 9) & $0.15(0.09)$ & $\mathrm{NS}$ \\
Wool quality (1 to 9) & $-0.04(0.08)$ & $\mathrm{NS}$ \\
Age at first lambing, d & $-4.58(3.57)$ & $\mathrm{NS}$ \\
First-lambing interval, d & $4.99(9.12)$ & $\mathrm{NS}$ \\
Second-lambing interval, d & $1.71(10.4)$ & $\mathrm{NS}$ \\
Total born lambs, no. & $-0.002(0.05)$ & $\mathrm{NS}$ \\
Milk yield, kg & $0.08(0.10)$ & $\mathrm{NS}$ \\
Fat content, \% & $0.18(0.13)$ & $\mathrm{NS}$ \\
Fat yield, g & $9.25(6.43)$ & $\mathrm{NS}$ \\
Protein content, \% & $-0.04(0.07)$ & $\mathrm{NS}$ \\
Protein yield, g & $3.25(5.12)$ & $\mathrm{NS}$ \\
SCS & $0.12(0.29)$ & $\mathrm{NS}$ \\
\hline
\end{tabular}

${ }^{1} \mathrm{xxx}=\mathrm{AHQ}, \mathrm{ARQ}$ alleles.

mance, type, or reproduction traits in different sheep breeds. With this study, a first analysis for possible associations between PrP genotyped dairy ewes and milk production, as well as reproduction traits and $\operatorname{PrP}$ genotyped rams and ewes and type traits, wool quality, and muscle mass in East Friesian milk sheep was done, but further studies are needed.

We were not able to include ARR/ARR homozygous milk sheep in our study because of the low numbers of these animals. Therefore, no conclusions are possible on the genotypic effects of animals homozygous for the ARR allele. Moreover, many other traits and breeds have not yet been examined, and associations to other traits or in other breeds are to be expected. Associations between the ARR allele and other traits are possible through linked or pleiotropic effects or through nonrandom sampling of animals. No linkage disequilibrium is known to exist between a PrP allele and a certain quantitative trait locus for any performance trait on chromosome 13. Nor is there any evidence of pleiotropic effects or associations caused by the accumulation of many small gene effects from gene loci randomly distributed over the chromosomes. Nevertheless, a breeding program for resistance to scrapie should take into consideration relationship coefficients, inbreeding rates within populations, and possible negative side effects caused by the necessity of intensively using the low numbers of breeding animals homozygous for ARR for upgrading a breed.

\section{CONCLUSIONS}

The data analyzed so far provided no evidence of any unfavorable association between the ARR allele and milk performance, type, or reproduction traits in East Friesian milk sheep.

\section{ACKNOWLEDGMENTS}

Financial support for this work was provided by the Lower Saxony Ministry for Rural Areas, Nutrition, Agriculture, and Consumer Protection and the Lower Saxony Animal Disease/Epizootic Reparation Fund. Frerich de Vries was supported by a grant from the Friedrich-EbertFoundation (Bonn, Berlin). The authors thank the sheep breeding organizations Landes-Schafzuchtverband Weser-Ems e.V., Landesschafzuchtverband Niedersachsen, and Vereinigung Westfälischer Herdbuchschafzüchter e.V. for providing blood samples and performance data. Moreover, the authors thank all staff members of the Institute for Animal Breeding and Genetics who provided technical assistance.

\section{REFERENCES}

Barillet, F., O. Andreoletti, I. Palhière, X. Aguerre, J. M. Arranz, S. Minery, C. Soulas, J. P. Belloc, M. Briois, G. Frégeat, P. Teinturier, Y. Amigues, J. M. Astruc, M. Y. Boscher, and F. Schelcher. 2002. Breeding for scrapie resistance using PrP genotyping in the French dairy sheep breeds. 7th World Congr. Genet. Appl. Livest. Prod., Montpellier, August 19-23, 2002, Vol. 31:683-686.

Barillet, F., and D. Boichard. 1987. Studies on dairy production of milking ewes. 1. Estimation of genetic parameters for total milk composition and yield. Genet. Sel. Evol. 19:459-474.

Belt, P. B., I. H. Muileman, B. E. C. Schreuder, J. B. Ruijter, A. L. Gielkens, and M. A. Smits. 1995. Identification of five allelic variants of the sheep PrP gene and their association with natural scrapie. J. Gen. Virol. 76:509-517.

Brandsma, J. H., L. L. G. Janss, and A. H. Visscher. 2004. Association between $\operatorname{PrP}$ genotypes and litter size and 135 days weight in Texel sheep. Livest. Prod. Sci. 86:59-64.

Commission Decision (2003/100/EC) of 13 February 2003. Laying Down Minimum Requirements for the Establishment of Breeding Programmes for Resistance to Transmissible Spongiform Encephalopathies in Sheep (Text with EEA relevance) (notified under document number C (2003) 498). Official J. L 041, 14/02/ 2003:41-45.

De Vries, F., N. Borchers, C. Drögemüller, H. Hamann, S. Reinecke, W. Lüpping, and O. Distl. 2004a. Analysis of associations between the prion protein genotype and performance traits in meat sheep breeds. Vet. Rec. 155:140-143.

De Vries, F., H. Hamann, and O. Distl. 2004b. Estimation of genetic parameters in meat and milk sheep breeds. Züchtungskunde $76: 117-126$.

De Vries, F., H. Hamann, and O. Distl. 2004c. Estimation of genetic parameters in land sheep breeds. [German]. Archiv Tierzucht. 47:351-358.

Drögemüller, C., F. De Vries, H. Hamann, T. Leeb, and O. Distl. 2004. Breeding German sheep for resistance to scrapie. Vet. Rec. 154:257-260.

Drögemüller, C., T. Leeb, and O. Distl. 2001. PrP genotype frequencies in German breeding sheep and the potential to breed for resistance to scrapie. Vet. Rec. 149:349-352.

El-Saied, U. M., J. A. Carriedo, and F. San Primitivo. 1998. Heritability of test-day somatic cell counts and its relationship to milk yield and protein percentage in dairy ewes. J. Dairy Sci. 81:2956-2961.

Goldmann, W., N. Hunter, G. Benson, J. D. Foster, and J. Hope. 1991. Different scrapie-associated fibril proteins (PrP) are encoded in lines of sheep selected for different alleles of the Sip gene. J. Gen. Virol. 72:2411-2477.

Groeneveld, E. 1993. PEST User's Manual. Institute for Animal Husbandry and Animal Behaviour, Federal Agriculture Research Centre (FAL), Neustadt, Germany. 
Groeneveld, E. 1998. VCE4 User's Guide and Reference Manual Version 1.1. Institute for Animal Science and Animal Husbandry, Federal Agricultural Research Centre (FAL), Neustadt, Germany.

Hamann, H., A. Horstick, A. Wessels, and O. Distl. 2004. Estimation of genetic parameters for test-day milk production, somatic cell score and litter size at birth in East Friesian ewes. Livest. Prod. Sci. 87:153-160.

Heggebø, R., C. M. L. Press, G. Gunnes, L. González, and M. Jeffrey. 2002. Distribution and accumulation of $\mathrm{PrP}$ in gut-associated and peripheral lymphoid tissue of scrapie-affected Suffolk sheep. J. Gen. Virol. 83:479-489.

Heggebø, R., C. M. L. Press, G. Gunnes, M. J. Ulvund, M. A. Tranulis, and T. Landsverk. 2003. Detection of PrPSc in lymphoid tissues of lambs experimentally exposed to the scrapie agent. J. Comp. Pathol. 128:172-181.

Hunter, N., J. D. Foster, W. Goldmann, M. J. Stear, J. Hope, and C. Bostock. 1996. Natural scrapie in a closed flock of Cheviot sheep occurs only in specific PrP geneotypes. Arch. Virol. 141:809-824.

Hunter, N., W. Goldmann, J. D. Foster, D. Cairns, and G. Smith. 1997. Natural scrapie and PrP genotype: Case control studies in British sheep. Vet. Rec. 141:137-140.

Hunter, N., W. Goldmann, G. Smith, and J. Hope. 1994. The association of a codon-136 PrP gene variant with the occurrence of natural scrapie. Arch. Virol. 137:171-177.

Ligda, C., G. Gabriilidis, T. Papadopoulos, and A. Georgoudis. 2000. Estimation of genetic parameters for production traits of Chios sheep using a multitrait animal model. Livest. Prod. Sci. $66: 217-221$

Matika, O., J. B. van Wyk, G. J. Erasmus, and R. L. Baker. 2003. Genetic parameter estimates in Sabi sheep. Livest. Prod. Sci. 79:17-28.

Parry, H. B. 1983. The agricultural importance of scrapie. Pages 150 153 in Scrapie Disease in Sheep. D. R. Oppenheimer, ed. Academic Press, London, UK.

Prokopová, L., R. M. Lewis, W. S. Dingwall, and G. Simm. 2002. Scrapie genotype: A association with lean growth rate? 7th World Congr. Genet. Appl. Livest. Prod., Montpellier, August 19-23, 2002, Vol. 31:779-782.

Rupp, R., G. Lagriffoul, J. M. Astruc, and F. Barillet. 2002. Genetic parameters for milk somatic cell scores and relationships with production traits in French Lacaune dairy sheep. J. Dairy Sci. 86:1476-1481.

Savas, T., R. Röhe, and E. Kalm. 2000. Estimation of genetic parameters for reproduction traits in sheep. Züchtungskunde 72:217229 .

Savas, T., R. Röhe, and E. Kalm. 2001. Genetic statistical analysis of field data on fattening and carcass composition traits in meat sheep breeds from Schleswig-Holstein. Züchtungskunde 73:6273.

Stier, C. H., S. von Korn, and K. J. Peters. 1988. Meat performance testing in sheep. 3rd communication: Genetic variability and heritability of meat performance traits recorded under farm, licensing and station conditions and approaches to optimize the meat performance testing scheme of sheep in Lower Saxony. Züchtungskunde 60:123-134. 